MUDRA: Journal of Finance and Accounting, Volume 4, Issue 2, July-December 2017, pp. 95-111 doi: 10.17492/mudra.v4i02.11451

\title{
An Empirical Study on the Performance of Select Multicap Equity Mutual Funds in India
}

\author{
Deepika Kamboj* and Shukrant Jagotra**
}

\begin{abstract}
Mutual funds are emerging as a popular choice among investors to park their surplus funds in India as exemplified by increasing assets under management (AUM). The study discusses several industry trends such as increase in mutual fund accounts and schemes, changing consumer preferences towards equity mutual funds and the increasing role of retail investors in the overall mutual fund market. While barriers continue to act as deterrents, the overall industry is poised to reach INR20,00,000 crore in terms of AUM by FY18. The study aims to evaluate the annual as well as periodical performance of 5 multicap mutual fund schemes of top 5 asset management companies for the period of five years from $1^{\text {st }}$ April 2012 to $31^{\text {st }}$ March 2017. Taking S\&P BSE 500 as the benchmark index, the study computes several absolute and relative performance measures using Sharp and Treynor Ratios along with Jensen Alpha. The study finds that all schemes except HDFC Premier Multicap fund generated higher risk adjusted returns than the benchmark index. Birla Sunlife Equity fund emerged as the best performer with higher average returns and lower risk.
\end{abstract}

Keywords: Multicap mutual funds; Returns; Risk; Sharpe Ratio; Treynor Ratio; Jensen Alpha.

\subsection{Introduction}

Investment, an important aspect of financial management, refers to the commitment of certain surplus funds to an asset class for the purpose of earning certain or uncertain rewards in the future. All investment decisions are a trade-off between risk and return. While there are several asset classes to invest such as certificate of deposits, stock,

*Corresponding author; Assistant Professor, Dev Samaj College for Women, Chandigarh, India. (Email id: deepikakamboj.ubs@gmail.com)

** Research Scholar, School of Management Studies, Punjabi University, Patiala, Punjab, India. (Email id: shukrant.jagotra.ubs@gmail.com) 
96 MUDRA: Journal of Finance and Accounting, Volume 4, Issue 2, Jul-Dec 2017

exchange traded funds, gold, and real estate etc., mutual funds are becoming a popular choice of investment in India due to its several advantages such as professional management, diversification to reduce overall portfolio risk, high liquidity and flexibility along with others.

Mutual fund is a professionally managed trust that pools all the funds received from a number of investors and invests them into several securities such as shares, bonds, commodities and short-term securities according to the fund's investment objective. Mutual funds can be categorized on the basis of maturity period, investment objective and others. In terms of maturity period, there are open or closed-ended mutual funds, while on the basis of investment objectives there are equity, debt, balanced (comprising both equity and debt), liquid or money market and gilt based mutual funds.

The mutual fund industry in India started in 1963 with the establishment of Unit Trust of India (UTI) by Reserve Bank of India (RBI). RBI held regulatory and administrative control over UTI until 1978 after which the duties were transferred to the Industrial Development Bank of India. Realizing the detriments of prohibiting the entry of non-UTI fund houses in terms of slow growth, the government opened the mutual fund industry in 1987 and 1993 to mark the entry of other public and private sector fund houses respectively. Following the repeal of the UTI Act of 1963, UTI was bifurcated into two separate entities as UTI I and UTI II.

Through all the above mentioned reforms, mutual fund industry in India has grown many folds over the past few decades to reach INR18,29,584 crores in terms of AUM with over 40 mutual fund houses operating in March 2017. ICICI Prudential Asset Management, HDFC Asset Management and Reliance Nippon Life Asset Management are the three largest mutual fund houses in India with an AUM of INR 2,42,961, INR 2,37,178 and INR2,10,891 (all figures in crores) respectively as on March 2017 (Association of Mutual Funds in India). Some of the major trends in the industry are highlighted below:

a. Strong growth in asset under management: Mutual fund industry has grown at a compounded annual growth rate of over 17\% from INR 7,00,538 crores in FY11 to reach INR 18,29,584 crores in FY17 and is expected to cross the INR20,00,000 crores mark in FY18 (Association of Mutual Funds in India) (Figure 1). Increased mutual fund knowledge coupled with strong growth in overall equity markets can be attributed towards this tremendous growth.

b. Increase in number of mutual fund schemes and investor accounts: Investors' choices to choose a mutual fund scheme has more than doubled from 1,131 in FY11 to 2,281 in FY17. Primary cause for this overall increase in number of schemes is due to the staggering increase in number of income funds from 591 in FY11 to a 
staggering 1,575 in FY17. Apart from increase in number of schemes, the total number of mutual fund accounts have also increased substantially. While the total mutual fund accounts across investor type decreased from 4.72 crores in FY11 to 3.95 in FY14, they increased sharply since then to reach 5.54 crores in FY17. Retail investors contributed around $99 \%$ of these total accounts (Association of Mutual Funds in India).

c. Changing consumer preferences: Growing interest in equity markets led to an increase in proportion of equity mutual funds assets in the overall mutual funds from $22.1 \%$ in March 2014 to $32.8 \%$ in March 2017. On the other hand, the proportion of debt oriented mutual funds fell from 52\% to 42.1\% in March 2014 and March 2017 respectively (Association of Mutual Funds in India).

\section{Figure 1: Average Asset under Management (in INR crores)}

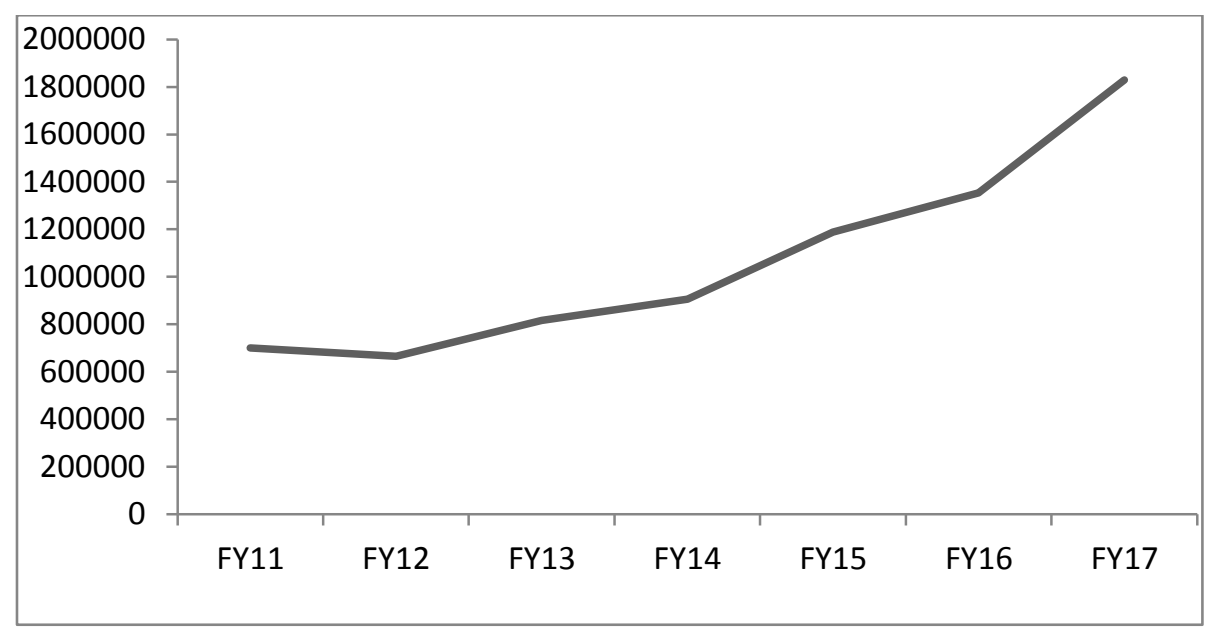

Source: Association of Mutual Funds in India

While these trends demonstrate strong opportunity for the mutual fund industry in India, several barriers including low distribution network and product awareness leading to lower mutual fund penetration among tier II \& below cities coupled with higher expense ratio as compared to global standards continue to hinder its future development path in India.

The paper aims to evaluate the performance of 5 multicap mutual funds of top fund houses in India (as per their AUM in Jan-Mar 2017 quarter) for the period of five years from $1^{\text {st }}$ April 2012 to $31^{\text {st }}$ March 2017. 
98 MUDRA: Journal of Finance and Accounting, Volume 4, Issue 2, Jul-Dec 2017

\subsection{Review of Literature}

Sondhi and Jain (2005) evaluated 17 public and 19 private sector equity based mutual fund schemes against 365 days T-bills and BSE 100 Index for the period of ten years from 1993 to 2002 . The study revealed that the mean and median returns of these schemes were lower than the returns on 365 days T- bills and higher than the BSE 100 index. The study showed that private equity schemes performed much better due to its popularity, fund management practices, well-researched stock selection and timing skills. More than $75 \%$ of public sector schemes were unable to achieve better returns despite of higher investor confidence associated with higher safety.

Muthappan and Damodharan (2006) evaluated 40 schemes for the period of five years from April 1995 to March 2000 against 91 days Treasury Bills (benchmark). The performance of Mutual Funds was evaluated using measures of Risk \& Return, Beta, Treynor's Ratio, Sharpe's Ratio and Jensen's Alpha. The study revealed that majority of the schemes earned returns higher than the market returns but lower than 91 days T-bill rate. 15 out of 40 schemes showed an above average monthly return. The study found that 23 out of 40 schemes outperformed both in terms of total risk and systematic risk while 19 schemes with positive alpha values implied superior performance. The study concluded that the Indian Mutual Funds were not appropriately diversified.

Varghese \& Murthy (2009) analysed 20 equity diversified schemes from 2007 to 2009 by comparing their net asset value (NAV) with the benchmark index, Nifty. The schemes selected for the study were the top equity diversified segment published by ICICI direct for the year ended 2007. The computed values for Sharpe, Treynor and Jensen Alpha were positive for all schemes. The study showed that while the schemes demonstrated good risk-adjusted performance, their beta values revealed that there existed a considerable amount of risk while investing in these schemes. According to the study, investing in Birla Sunlife Frontline Equity Fund, DSPML India Tiger Fund, SBI Magnum Contra Fund, SBI Magnum Global Fund and Sundaram Select Midcap Fund, was highly beneficial during that period of time.

Ashraf \& Sharma (2013) attempted to analyse the performance of equity mutual funds against risk-free rate of return and benchmark returns over a period of five years from April 2007 to March 2012. They analysed a sample of 10 open-ended equity mutual fund schemes offered by 5 public and 2 private mutual fund houses. The risk-return analysis showed that 3 out of the 10 schemes performed inferior to the market while as many as 7 schemes had lower risk than the market. While the Treynor's Ratio of all mutual funds showed better performance than the benchmark index, Sharpe Ratio of three mutual fund schemes showed under performance than the benchmark index. The study 
concluded by performing regression analysis and suggested that returns from the benchmark index has statistically significant impact on mutual fund returns at a significance level of $5 \%$.

Burlakanti \& Chiruvoori (2013) aimed to analyse the risk and return relationship among top 10 mutual fund schemes (Birla Sunlife Gennext Growth, Franklin Indian Prima Plus, HDFC Growth Fund, ING Dividend Yield, Kotak Opportunities Fund, Principal Dividend Yield, Quantum Long-Term Equity, Reliance Equity Opportunities, TATA Dividend Yield Fund and UTI MNC Fund) from December 2007 to December 2012. The study found that mutual fund schemes justified the presence of higher volatility by generating superior returns for its investors. The study found that TATA Dividend Yield fund and ING Dividend Yield fund showed consistent and superior returns in comparison to others. The research also advised that mutual fund investors should stay invested for a longer period of time rather to reduce volatility while boosting higher returns.

Choudhary \& Chawla (2014) attempted to analyse the performance of eight growth-oriented, open-ended equity diversified schemes viz. SBI Contra Fund, Kotak Opportunities Fund, Birla Sunlife Dividend Yield Plus Fund, HDFC Growth Fund, ICICI Prudential Dynamic Plan Fund, Tata Ethical Fund, UTI MNC Fund and HSBC India Opportunities Fund. The analysis revealed that as much as $75 \%$ of the sample schemes showed superior returns in terms of average returns, while $62 \%$ of the schemes considered were less risky than the market in terms of standard deviation. The value of coefficient of determination was near 1 implying higher diversification of portfolio. All the funds except HSBC India opportunities Fund showed better performance under the Sharpe ratio as well as Treynor Ratio.

Kaur (2014) examined the performance of 23 open-ended debt mutual funds and compared weekly returns to benchmark returns in India from $1^{\text {st }}$ July 2010 to $30^{\text {th }}$ June 2011. The average weekly returns were calculated on the basis of percentage change in NAV. The analysis revealed that most of the schemes were unable to perform better in comparison to benchmark index. The schemes showed higher variability in returns and demonstrated the defensive nature of schemes and less sensitivity to market forces. Analysis revealed that none of the schemes performed better with respect to Sharpe and Jensen measure while $26 \%$ of the schemes performed better in the market with respect to Treynor's Ratio. The study concluded that most funds performed poorly in comparison to benchmark index due to poor fund management.

Ranjan \& Gupta (2014) selected top 5 asset management companies as per their AUM on $30^{\text {th }}$ September 2014. The funds selected for the purpose of study were HDFC Equity Fund, ICICI Prudential Top 200 Fund, Reliance Growth, UTI Mid Cap Fund and 
Birla Sun Life Equity Fund and their performance was accessed against BSE Sensex (Benchmark Index). The data, collected for a time period of 5 years from 2010 to 2014, was analysed through the measures of Annual returns, Beta, Treynor's ratio, Sharpe's ratio and Jensen's alpha. Different funds reflected different values in all measures, however, it was found that the best performing fund of all was HDFC Equity Fund as it yielded positive results through all measures.

Das (2015) analysed the performance of 14 funds chosen from 12 fund houses and ranked them under 7 performance measures viz. return, standard deviation, Sharpe Ratio, Treynor Ratio, return from systematic investment plan, Jensen Alpha and coefficient of determination (RSQ) for five different time periods spanning 1, 3, 5, 7 and 10 years each. The study concluded that most of the funds were able to beat the benchmark index with UTI Equity Fund and Sundaram Select Focus Fund emerging as the top and worst performer respectively. The RSQ of all funds was also found out to be in excess of 0.8 .

Goyal (2015) evaluated the performance of top 10 mutual funds as per the Crisil ranking of mutual funds in September namely Birla Sun Life Top 100 Fund, BNP Paribas Equity Fund, SBI Blue Chip Fund, UTI Equity Fund, Birla Sun Life Frontline Equity Fund, BOI AXA Equity Fund, Canara Robeco Large Cap Fund, Franklin India Opportunities Fund, Kotak Opportunities and L\&T Equity Fund, in reference with S\&P CNX Nifty. The daily closing NAVs from $1^{\text {st }}$ August 2014 to $9^{\text {th }}$ November 2014 was used for the purpose of study. The study rated Franklin India Opportunities fund as the top performing fund during that period of time, as it showed less variability and higher Sharpe's ratio, Treynor ratio and Jensen Alpha.

Raju et. al. (2015) evaluated mutual fund performance in India by using William, Sharpe, Treynor and Jensen's models for growth oriented schemes floated by selected funds in operation from past 10 years. These schemes considered for the study included Franklin Asian equity Fund, Axis Equity fund, Quantum equity Fund of Fund, Reliance Equity opportunities Fund and UTI opportunities Fund. They analysed data for a period of 2 years form January 2012 to January 2014 against the benchmark index, BSE-100. The study revealed that mutual funds schemes were yielding good returns in comparison to benchmark and hence is suggested as a better investment opportunity. It suggested that while Quantum Equity fund is suitable for aggressive investors, Franklin Asia Equity Fund was suitable for conservative investors.

Masiperiyannan et. al. (2016) attempted to analyse and evaluate the performance of 10 open-ended mutual fund schemes for a period of 6 years from April 1, 2010 to March 31, 2015. These schemes were Birla Sun Life Frontline Equity Fund, BNP Paribas Equity Fund, Franklin India Opportunities Fund, Kotak 50, UTI Equity Fund, Baroda 
Pioneer Growth Fund, JM Equity Fund, JP Morgan India Equity Fund, Principal Large Cap Fund and UTI Master Share Unit Scheme. For the purpose of analysis BSE Sensex was used as benchmark Index. The study revealed that Kotak 50 growth fund performed better in comparison to other funds and UTI Master Share Unit Scheme is the worst performing fund.

\subsection{Objectives of the Study}

The study has been conducted to achieve the following major objectives viz.:

(i) To evaluate the performance of multicap mutual fund schemes against the returns of benchmark index, S\&P BSE 500;

(ii) To identify the risk-return relationship and market volatility of selected multicap mutual fund schemes; and

(iii) To analyse the risk-adjusted performance of selected multicap mutual fund schemes through techniques such as Sharpe Ratio, Treynor Ratio and Jensen's Alpha.

\subsection{Need for study}

The need for the study arises on account of the following:

a. Majority of the past literature is based on Large Cap or Monthly Income Plan (MIP) mutual fund schemes. However, very less literature is available on the Multicap mutual fund schemes which are emerging as a popular choice among the investors.

b. Significant policy and regulatory changes coupled with recent developments such as low inflation, demonetisation, and volatility in stock markets are changing the face of financial markets in India including Mutual Funds. All these developments build a strong case to re-examine the performance of mutual funds.

c. Mutual funds are based on certain objectives and are driven by specific investment philosophy. Very few funds have generated consistent returns by beating the benchmark index as this investment philosophy is vulnerable to economic growth cycles. Thus there is a strong need to re-identify consistent mutual fund performers.

\subsection{Research Methodology}

a. Stock market selected for the study: Bombay Stock Exchange (BSE)

b. Benchmark Index selected for performance evaluation: As the study deals with the performance evaluation of multicap mutual funds, which as per their name suggests can invest across stocks of various market capitalisations, S\&P BSE 500 index is chosen as the benchmark index for the study. The S\&P BSE 500 index represents 
nearly $93 \%$ of the total market capitalization on BSE covering all 20 major industries of the economy.

c. Fund House and Mutual Fund Schemes selected for performance evaluation: The study chose multicap mutual funds of top 5 fund houses on the basis of their average asset under management (AUM, for the quarter ended in March 2017) (Table 1).

Table 1: Multicap Mutual Funds Schemes selected for Performance Evaluation*

\begin{tabular}{|l|c|l|}
\hline \multicolumn{1}{|c|}{ Fund House } & Average AUM** & \multicolumn{1}{c|}{ Scheme Name } \\
\hline ICICI Prudential Asset Management & $2,429.6$ & ICICI Prudential Multicap \\
\hline HDFC Asset Management & $2,371.2$ & HDFC Premier Multicap \\
\hline Reliance Nippon Life Asset Management & $2,108.9$ & Reliance Equity Opportunities \\
\hline Birla Sunlife Asset Management & $1,950.9$ & Birla Sunlife Equity \\
\hline SBI Funds Management & $1,570.3$ & SBI Magnum Multicap \\
\hline
\end{tabular}

Source: Association of Mutual Funds in India Monthly Report

Notes: *Regular growth plan of all mutual funds are taken

**All values for asset under management are in INR billion

d. Time frame: The study considered monthly closing data for 5 years i.e. from April 1, 2012 to March 31, 2017 for the purpose of calculation and analysis.

e. Data source: The study used secondary data of month-end closing value and net asset value (NAV) for benchmark index as well as mutual funds respectively. While the data for benchmark index has been extracted from the website of Bombay Stock Exchange, data for NAVs for mutual funds has been taken from Association of Mutual Funds in India (AMFI).

f. Method of calculation: The study considered month-endclosing values of S\&P BSE 500 as well as NAVs of the above mentioned 5 multicap mutual funds over a period of 5 years (April 1, 2012 to March 31, 2017). After calculating monthly returns for S\&P BSE 500 and mutual funds, the study estimated several other parameters to evaluate their performance such as Standard Deviation, Beta Factor, Sharpe Ratio, Treynor ratio and Jensen's Alpha for both annually (from 2013 to 2017) as well as for a single consolidated value for this period.

Monthly Mutual Fund and S\&P BSE 500 returns have been calculated using the formula:

where,

$$
\mathrm{y}_{\mathrm{i}}=\left(\mathrm{P}_{\mathrm{i}+1}-\mathrm{P}_{\mathrm{i}}\right)^{*} 100 / \mathrm{P}_{\mathrm{i}}
$$

$\mathrm{y}_{\mathrm{i}}=$ Monthly return of mutual fund or S\&P BSE 500 in \% terms

$\mathrm{P}_{\mathrm{i}+1}=$ Net asset value of mutual fund or value of S\&P BSE 500 on (i+1 $)^{\text {th }}$ month 
$\mathrm{P}_{\mathrm{i}}=$ Net asset value of mutual fund or value of S\&P BSE 500 on $\mathrm{i}^{\text {th }}$ month

After calculating the monthly returns for calculating the standard deviation and beta factor, annual as well as periodical returns have been calculated. Apart from depicting the trend in comparison with the benchmark index, these values are also leveraged as an input value in computing several parameters discussed further.

Beta-coefficient or systematic risk or non-diversifiable risk is that portion of the total risk that cannot be eliminated even by building a well-diversified portfolio. The beta for the market (or in this study S\&P BSE 500) is by default taken as 1 and all other values are computed in reference with this value. The value of beta factor for all five mutual funds has been calculated using the following formula:

$$
\beta=\left(n \sum x y-\sum x \sum y\right) / n \sum x^{2}-\left(\sum x\right)^{2}
$$

where,

$\mathrm{x}=$ monthly returns of S\&P BSE 500 Index

$y=$ monthly returns of each of the 5 multicap mutual fund schemes

$\mathrm{n}=$ number of observations

The beta factor for each of the mutual funds has been calculated on both the annual as well as periodical basis. Number of observations is taken as 11 and 59 in annual and periodical beta factor computations respectively.

Standard deviation is a measure of total risk. It measures the fluctuations in NAVs with respect to the average returns during a period. Standard deviation of monthly returns for each mutual fund scheme as well as for S\&P BSE 500 has been calculated using the formula:

where,

$$
\sigma=\sqrt{ }(1 / \mathrm{N}) \sum\left(\mathrm{x}_{\mathrm{i}}-\mu\right)^{2}
$$

i varies from 1 to $\mathrm{N}$

$\sigma=$ standard deviation

$\mathrm{N}=$ number of observations

$\mathrm{x}_{\mathrm{i}}=$ monthly returns of mutual fund scheme or S\&P BSE 500

$\mu=$ mean of all observations

Standard deviation for all 5 mutual funds has been calculated on both the annual as well as periodical basis. Number of observations is taken as 11 and 59 in annual and periodical standard deviation computations respectively.

Developed by William F. Sharpe, the Sharpe's ratio is a measure of risk adjusted returns generated by the fund. The ratio computes the additional returns generated by the fund over the risk-free rate along with the total risk associated. As mutual fund investors are taking higher risk than investors investing in risk-free securities, the ratio highlights 
the reward per unit risk taken. Higher ratio signifies better fund performance. The ratio has been computed for both the mutual funds as well as for the benchmark index as:

where,

$$
\mathrm{S}_{\mathrm{MF}}=\left(\mathrm{R}_{\mathrm{MF}}-\mathrm{R}_{\mathrm{RF}}\right) / \sigma_{\mathrm{MF}} \text { OR } \mathrm{S}_{\mathrm{I}}=\left(\mathrm{R}_{\mathrm{I}}-\mathrm{R}_{\mathrm{RF}}\right) / \sigma_{\mathrm{I}}
$$

$\mathrm{R}_{\mathrm{MF}}=$ Annual or periodical mutual fund returns

$\mathrm{R}_{\mathrm{I}}=$ Annual or periodical benchmark index returns

$\mathrm{R}_{\mathrm{RF}}=$ Annual or periodical return on a risk-free security

$\sigma_{\mathrm{MF}}=$ Annual or periodical standard deviation of mutual fund returns

$\sigma_{\mathrm{I}}=$ Annual or periodical standard deviation of benchmark index returns

1 year term deposits are taken as the proxy for risk-free rate. As the rates have changed multiple times during FY13 to FY17, different rates have been taken for each year as mentioned in Table 2 .

Table 2: Risk-free Rates for Different Years

\begin{tabular}{|l|l|l|l|l|l|l|}
\hline & FY13 & FY14 & FY15 & FY16 & FY17 & FY13-17 \\
\hline Risk-free Rates & $8.75 \%$ & $8.9125 \%$ & $8.8125 \%$ & $7.5 \%$ & $7.0 \%$ & $48.2 \%$ \\
\hline
\end{tabular}

Developed by Jack Treynor, the Treynor's Ratio measures the additional reward per unit of systematic risk instead of standard deviation as used in the Sharpe's ratio. Also known as the reward to volatility ratio, the Treynor's ratio is appropriate for multicap funds considered in the study where majority of the diversifiable risk has been eliminated. It is measured as:

where,

$$
\mathrm{T}_{\mathrm{MF}}=\left(\mathrm{R}_{\mathrm{MF}}-\mathrm{R}_{\mathrm{RF}}\right) / \beta_{\mathrm{MF}} \text { OR } \mathrm{T}_{\mathrm{I}}=\left(\mathrm{R}_{\mathrm{I}}-\mathrm{R}_{\mathrm{RF}}\right)
$$

$\mathrm{R}_{\mathrm{MF}}=$ Annual or periodical mutual fund returns

$\mathrm{R}_{\mathrm{I}}=$ Annual or periodical benchmark index returns

$\mathrm{R}_{\mathrm{RF}}=$ Annual or periodical return on a risk-free security

$\beta_{\mathrm{MF}}=$ Annual or periodical beta-coefficient of mutual fund returns

Also known as Jensen Alpha, the Jensen measure helps in evaluating the fund manager's ability to select undervalued securities in order to generate superior return than the benchmark index. In other words, the Jensen measure represents the average return generated over and above the returns computed as per the capital asset pricing model (CAPM). A positive alpha value highlights excess returns than the returns as per the CAPM model, which is equal to the benchmark returns. It is measured as:

$$
\text { Jensen Measure }=R_{M F}-\left(R_{R F}+\beta_{M F}\left(R_{I^{-}} R_{R F}\right)\right.
$$


where,

$\mathrm{R}_{\mathrm{MF}}=$ Annual or periodical mutual fund returns

$\mathrm{R}_{\mathrm{RF}}=$ Annual or periodical return on a risk-free security

$\mathrm{R}_{\mathrm{RF}}=$ Annual or periodical benchmark index return

$\beta_{\mathrm{MF}}=$ Annual or periodical beta-coefficient of mutual fund returns

\subsection{Findings and Observations}

The section highlights the descriptive statistics as well as performance evaluation of top multicap mutual fund schemes.

\subsection{Returns of Selected Multicap Mutual Funds}

Table 3 below depicts the performance of these mutual fund schemes on annual basis from FY13 to FY17 and compares the same with the benchmark index, BSE 500. As can be seen from the Table 3, annual returns generated by SBI Magnum Multicap, ICICI Prudential Multicap and Birla Sunlife Equity beats the benchmark index returns every year during the period from FY13 to FY17. HDFC Premier Multicap demonstrated inferior performance than benchmark index during FY13 and FY16. Although the Reliance Equity Opportunities fund generated superior performance than the benchmark index as well as other funds, its performance dwindled post FY15 after which the fund failed to generate superior returns than BSE 500. Results of estimation of periodical returns from FY13 to FY17 are also shown in the last column. As per the analysis, Birla Sunlife Equity fund generated highest returns of $167 \%$ to its investors while the HDFC Premier Equity generated lowest return of $84 \%$, failing even to match the benchmark index returns of $89 \%$.

Table 3: Returns of Selected Multicap Mutual Funds

\begin{tabular}{|l|c|c|c|c|c|c|}
\hline \multicolumn{1}{|c|}{ Returns (in \%) } & FY13 & FY14 & FY15 & FY16 & FY17 & FY13-17 \\
\hline S\&P BSE 500 & 5.77 & 12.32 & 32.44 & $(4.78)$ & 21.39 & $\mathbf{8 8 . 5 8}$ \\
\hline ICICI Prudential Multicap & 7.65 & 18.52 & 41.26 & $(2.14)$ & 27.57 & $\mathbf{1 4 4 . 3 0}$ \\
\hline HDFC Premier Multicap & $(2.85)^{*}$ & 15.11 & 38.07 & $(10.64)^{*}$ & 25.74 & $\mathbf{8 4 . 3 6} *$ \\
\hline Reliance Equity Opportunities & 10.91 & 17.88 & 51.22 & $(8.36)^{*}$ & $18.37 *$ & $\mathbf{1 1 5 . 0 9}$ \\
\hline Birla Sunlife Equity & 7.75 & 20.84 & 48.07 & $(1.64)$ & 30.32 & $\mathbf{1 6 7 . 0 8}$ \\
\hline SBI Magnum Multicap & 8.02 & 13.83 & 52.07 & 2.62 & 22.62 & $\mathbf{1 4 7 . 9 2}$ \\
\hline
\end{tabular}

Note: *signifies inferior return than benchmark index returns 
106| MUDRA: Journal of Finance and Accounting, Volume 4, Issue 2, Jul-Dec 2017

\subsection{Beta-factor Values of Selected Multicap Mutual Funds}

Table 4 below analysis the beta factor values for each of the mutual funds annually by taking the benchmark index as the base reference at value 1 . Almost all mutual fund schemes showed a similar risk profile with beta factor values close to 1 except the HDFC Premier Multicap fund which had higher beta values of 1.28, 1.37 and 1.48 in FY14, FY15 and FY17 respectively. ICICI Prudential Multicap fund was the most consistent fund in terms of risk with the values of beta coefficient ranging within the smaller range of 0.87 to 1.03. In terms of periodical (FY13 to FY17) beta coefficient value for the period from FY13 to FY17, ICICI Prudential Multicap and SBI Magnum Multicap funds had the lowest risk with beta factor value of 0.96 . Similar to the yearly trend, HDFC Premier Multicap fund emerged as the most risky fund among the lot with $23 \%$ higher volatility than the market index.

Table 4: Beta-factor Values of Selected Multicap Mutual Funds

\begin{tabular}{|l|c|c|c|c|c|c|}
\hline \multicolumn{1}{|c|}{ Returns (in \%) } & FY13 & FY14 & FY15 & FY16 & FY17 & FY13-17 \\
\hline S\&P BSE 500 & 1 & 1 & 1 & 1 & 1 & $\mathbf{1}$ \\
\hline ICICI Prudential Multicap & 1.03 & 0.98 & 0.95 & 0.87 & 0.95 & $\mathbf{0 . 9 6}$ \\
\hline HDFC Premier Multicap & 1 & 1.28 & 1.37 & 1.49 & 0.87 & $\mathbf{1 . 2 3}$ \\
\hline Reliance Equity Opportunities & 0.88 & 0.93 & 1.02 & 1.15 & 0.96 & $\mathbf{1 . 0 2}$ \\
\hline Birla Sunlife Equity & 1.03 & 1.02 & 1.18 & 1.07 & 1 & $\mathbf{1 . 0 7}$ \\
\hline SBI Magnum Multicap & 0.80 & 1.00 & 0.79 & 1.14 & 1.00 & $\mathbf{0 . 9 6}$ \\
\hline
\end{tabular}

\subsection{Sharpe's Ratio of Selected Multicap Mutual Funds}

Table 5 evaluates the performance of mutual funds in terms of the additional returns generated than the risk free rate with respect to their associated risk measured by standard deviation. As per the formula, higher Sharpe's ratio signifies superior performance.

Table 5: Sharpe's Ratio of Selected Multicap Mutual Funds

\begin{tabular}{|l|c|c|c|c|c|c|}
\hline \multicolumn{1}{|c|}{ Sharpe's ratio } & FY13 & FY14 & FY15 & FY16 & FY17 & FY13-17 \\
\hline S\&P BSE 500 & $(0.63)$ & 0.71 & 5.93 & $(2.35)$ & 4.24 & $\mathbf{9 . 3 2}$ \\
\hline ICICI Prudential Multicap & $(0.22)$ & 2.02 & 8.22 & $(2.06)$ & 5.44 & $\mathbf{2 2 . 2 4}$ \\
\hline HDFC Premier Multicap & $(2.33)^{*}$ & 0.95 & $5.08^{*}$ & $(2.22)$ & 5.94 & $\mathbf{6 . 3 3} *$ \\
\hline Reliance Equity Opportunities & 0.49 & 1.77 & 9.31 & $(2.54)^{*}$ & $3.26^{*}$ & $\mathbf{1 4 . 0 5}$ \\
\hline Birla Sunlife Equity & $(0.2)$ & 2.37 & 7.82 & $(1.59)$ & 6.23 & $\mathbf{2 4 . 6 2}$ \\
\hline SBI Magnum Multicap & $(0.18)$ & 1.02 & 12.66 & $(0.81)$ & 4.37 & $\mathbf{2 2 . 9 9}$ \\
\hline
\end{tabular}

Note: * signifies inferior risk adjusted return than benchmark index 
All mutual fund schemes demonstrated higher risk adjusted returns than the benchmark index in all years except for the HFDC Premier Multicap and Reliance Opportunity fund. On periodical basis, Birla Sunlife Equity showed the strongest risk adjusted performance followed closely by SBI Magnum Multicap and ICICI Prudential Multicap funds. The overall risk adjusted performance for HDFC Premier Multicap was the lowest at just 6.33 .

\subsection{Treynor's Ratio of Selected Multicap Mutual Funds}

In contrast to the above method, the Treynor's ratio replaces the standard deviation with the beta factor as a measure of risk. Table 6 below depicts the Treynor ratio every year for each of the 5 mutual funds. It also depicts the consolidated value in the last column.

Table 6: Treynor's Ratio of Selected Multicap Mutual Funds

\begin{tabular}{|l|c|c|c|c|c|c|}
\hline Treynor's ratio & FY13 & FY14 & FY15 & FY16 & FY17 & FY13-17 \\
\hline S\&P BSE 500 & $(0.03)$ & 0.03 & 0.24 & $(0.12)$ & 0.14 & $\mathbf{0 . 4 0}$ \\
\hline ICICI Prudential Multicap & $(0.01)$ & 0.10 & 0.34 & $(0.11)$ & 0.22 & $\mathbf{1 . 0 0}$ \\
\hline HDFC Premier Multicap & $(0.12)^{*}$ & 0.05 & $0.21^{*}$ & $(0.12)^{*}$ & 0.22 & $\mathbf{0 . 2 9}$ \\
\hline Reliance Equity Opportunities & 0.02 & 0.10 & 0.42 & $(0.14)^{*}$ & $0.12^{*}$ & $\mathbf{0 . 6 6}$ \\
\hline Birla Sunlife Equity & $(0.01)$ & 0.12 & 0.33 & $(0.09)$ & 0.23 & $\mathbf{1 . 1 1}$ \\
\hline SBI Magnum Multicap & $(0.01)$ & 0.05 & 0.54 & $(0.04)$ & 0.15 & $\mathbf{1 . 0 4}$ \\
\hline
\end{tabular}

All mutual fund schemes have demonstrated higher Treynor's ratio than the benchmark index in all the years except for the HFDC Premier Multicap and Reliance Opportunity fund. The HDFC Premier Multicap fund showed inferior Treynor's ratio than the BSE 500 in FY13, FY15 and FY16. It also registered lowest periodical Treynor ratio of 0.29 compared to 0.40 of that of BSE 500. While the Reliance Equity Opportunities fund also registered lower Treynor's ratio in some years, it managed to produce superior ratio than BSE 500 over the full period. Similar to the Sharpe's ratio in periodical performance, Birla Sunlife Equity showed the highest value followed closely by SBI Magnum Multicap and ICICI Prudential Multicap funds.

\subsection{Jensen's Alpha value of Selected Multicap Mutual Funds}

The values in the Table 7 highlight the fund manager's ability to generate additional returns than the benchmark index by selecting undervalued stocks. Just like the two ratios discussed above, the higher the value of Jensen Alpha, better is the 
performance. As per Table 7, all funds except HDFC Premier Multicap as well as Reliance Equity Opportunities fund managed to earn higher returns than BSE 500 in all years. HDFC Premier Multicap fund performed the worst as it could not even register a positive Jensen Alpha value for the entire period.

Table 7: Jensen's Alpha Value of Selected Multicap Mutual Funds

\begin{tabular}{|l|c|c|c|c|c|c|}
\hline Jensen's Alpha value & FY13 & FY14 & FY15 & FY16 & FY17 & FY13-17 \\
\hline ICICI Prudential Multicap & 0.020 & 0.063 & 0.100 & 0.011 & 0.068 & $\mathbf{0 . 5 7 4}$ \\
\hline HDFC Premier Multicap & $(0.086)$ & 0.018 & $(0.031)$ & 0.002 & 0.063 & $\mathbf{( 0 . 1 3 4 )}$ \\
\hline Reliance Equity Opportunities & 0.048 & 0.058 & 0.183 & $(0.017)$ & $(0.025)$ & $\mathbf{0 . 2 5 8}$ \\
\hline Birla Sunlife Equity & 0.021 & 0.084 & 0.114 & 0.040 & 0.089 & $\mathbf{0 . 7 5 6}$ \\
\hline SBI Magnum Multicap & 0.017 & 0.015 & 0.245 & 0.091 & 0.008 & $\mathbf{0 . 6 0 9}$ \\
\hline
\end{tabular}

\subsection{Conclusion}

The mutual fund industry in India has more than doubled in the past three years in terms of AUM. The study discussed several trends prevalent in the industry and also highlighted some of the major barriers that it has to overcome in order to retain this growth. The study analysed top 5 multicap mutual fund schemes from FY12 to FY17 in both annual and consolidated periods.

From the results, it can be noted that almost all funds except HDFC Premier Multicap were able to beat the absolute returns of the benchmark BSE 500. While Reliance Equity Opportunities fund showed strong returns from FY12 to FY15, its performance dwindled post FY15 as compared to other schemes. On the other hand, the three schemes viz. Birla Sunlife Equity, SBI Magnum Multicap and ICICI Prudential Multicap fund demonstrated consistent risk adjusted performance throughout the years. HDFC Multicap fund emerged to be the most volatile of the lot (23\% more volatile than the benchmark index), while both ICICI Prudential Multicap and SBI Magnum Multicap fund were less volatile than the benchmark index. The study also measured risk adjusted performance using Shapre, Treynor and Jensen's Alpha. Despite underperforming in few years, Reliance Equity Opportunities fund was able to generate superior returns in the overall period (FY13-17), HDFC Premier Multicap fund emerged as the worst performer.

\subsection{Implications}

The study holds immense implications across various stakeholders namely investors, fund managers, academicians and regulators. For investors, the findings 
exemplifies how capital invested in mutual funds needs to be reviewed after every year as returns from even similar type of mutual funds can vary by as much as $100 \%$ (Birla Sunlife Equity fund generated 167\% compared to just $84 \%$ earned by HFDC Premier Multicap fund from FY12 to FY17) over the course of just 5 years. For mutual fund managers, the study ignites the need for investigating the strategy behind superior returns generated by other competitor asset management companies (the same can be done through thorough research based on scheme information document comprising objective, strategy and top holdings among others). For academicians, the study further strenghtens the foundation for research on emerging mutual fund categories such as dynamic funds. The findings of the study can also be used to compare the performance of similar mutual funds in other developing economies. For regulators (Securities Exchange Board of India), the study can help in further enhancing consumer protection and interest in terms of fair method of performance evaluation. One such example is the recent order by SEBI to AMC's to shift from current return metrics to total return index to guard consumer interest by showcasing more realistic returns against benchmark index.

\section{References}

A Newsletter of the Association of Mutual Funds in India, AMFI India. (2017, May). Retrieved from http://portal.amfiindia.com/spages/aqu-vol10-issueIV.pdf

Ashraf, S.H., \& Sharma, D. (2014). Performance evaluation of Indian equity mutual funds against established benchmarks index. International Journal of Accounting Research, doi: 10.4172/2472-114X.1000113

Birla Sunlife Equity Fund, Birla Sunlife Fund. (2017, April). Retrieved fromhttp://mutualfund.birlasunlife.com/individual/our-solutions/wealth-creation/birlasunlife-equity-fund.aspx

Burlakanti, K., \& Chiruvoori, R.V. (2013). Performance evaluation of select equity funds in India. International Journal of Social Science \& Interdisciplinary Research, 2(5), 6978.

Choudhary, V., \& Chawla, P.S. (2014). Performance evaluation of mutual funds: A study of selected diversified equity mutual funds in India. International Conference on Business, Law and Corporate Social Responsibility (ICBLCSR'14), Oct 1-2, Phuket (Thailand). 
Das, S. (2015). An empirical study on the performance of select large cap equity mutual funds in India. MUDRA: Journal of Finance and Accounting, 2(1), 52-70

Goyal, M.M. (2015). Performance evaluation of top 10 mutual funds in India. Indian Journal of Commerce and Management Studies, 6(1), 51-55.

HDFC Premier Multi Cap Fund, HDFC Fund. (2017, May). Retrieved from http://www.hdfcfund.com/scheme-details/bdf299ee-f0ec-4a65-869d-d1892cfaa65a

ICICI Prudential Multi Cap Fund, ICICI Fund. (2017, May). Retrieved from https://www.icicipruamc.com/icici-prudential-mutual-fund/funds/equity-funds/iciciprudential-multicap-fund

Kaur, R. (2014). Performance evaluation of debt mutual fund schemes in India. GALAXY International Interdisciplinary Research Journal, 2(2), 180-192.

Latest Mutual Fund NAVs, Moneycontrol. (2017, May). Retrieved from http://www.moneycontrol.com/india/mutualfunds/mfinfo/16/40/latestnav

Masiperiyannan, S., \& P.M. (2016). Performance evaluation of selected open-ended mutual funds in India. International Journal of Business and Management Invention, $5(11), 136-142$.

Muthappan, P. K., \& Damodharan, E.(2006). Risk-adjusted performance evaluation of Indian mutual funds schemes. Finance India, 20(3), 965-983.

Mutual Fund Data for The Quarter January to March, AMFI India.(2017). Retrieved from http://portal.amfiindia.com/spages/aqu-vol16-issueIV.pdf

Raju, J.K., Manjunath, B.R., \& Nagaraja, G.M. (2015). Performance evaluation of Indian equity mutual funds schemes. Journal of Business Management and Social Sciences Research, 4(11), 600-610.

Ranjan, S., \& Gupta, S. (2014). Performance appraisal of mutual funds operating in India. Journal of Commerce and Trade, 9(2), 54-62. 
Reliance Equity Opportunity Fund, Reliance Fund. (2017, May). Retrieved from https://www.reliancemutual.com/FundsAndPerformance/Pages/Reliance-EquityOpportunities-Fund.aspx

SBI Magnum Multi Cap Fund, SBI Fund. (2017, May). Retrieved from https://www.sbimf.com/en-us/equity-schemes/sbi-magnum-multicap-fund

Sondhi, H. J., \& Jain, P. K. (2005). Financial management of private and public equity mutual funds in India: An analysis of profitability. The ICFAI Journal of Applied Finance, 2(6), 14-27.

Varghese, R. \& Murthy, K. (2009). Performance evaluation of equity diversified mutual funds in India. PCMA Journal of Business, 1(2). 32-50. 